\title{
HPV Transforming Protein E6 Antibody
}

National Cancer Institute

\section{Source}

National Cancer Institute. HPV Transforming Protein E6 Antibody. NCI Thesaurus. Code C129667.

Any immunog lobulin that recognizes HPV transforming protein E6. 